\title{
Treated Coconut Coir Pith as Component of Cementitious Materials
}

\author{
Dana Koňáková, ${ }^{1}$ Eva Vejmelková, ${ }^{1,2}$ Monika Čáchová, ${ }^{1}$ Jamal Akhter Siddique, ${ }^{1}$ \\ Kirill Polozhiy, ${ }^{1,2}$ Pavel Reiterman, ${ }^{2,3}$ Martin Keppert, ${ }^{1,2}$ and Robert Černý ${ }^{1,2}$ \\ ${ }^{1}$ Department of Materials Engineering and Chemistry, Faculty of Civil Engineering, Czech Technical University in Prague, \\ Thákurova 7, 16629 Prague 6, Czech Republic \\ ${ }^{2}$ University Centre for Energy Efficient Buildings, Třinecká 1024, 27343 Buštěhrad, Czech Republic \\ ${ }^{3}$ Experimental Centre, Faculty of Civil Engineering, Czech Technical University in Prague, Thákurova 7, \\ 16629 Prague 6, Czech Republic
}

Correspondence should be addressed to Martin Keppert; martin.keppert@fsv.cvut.cz

Received 17 April 2015; Accepted 4 August 2015

Academic Editor: Peter Majewski

Copyright (C) 2015 Dana Koňáková et al. This is an open access article distributed under the Creative Commons Attribution License, which permits unrestricted use, distribution, and reproduction in any medium, provided the original work is properly cited.

\begin{abstract}
The presented paper deals with utilization of raw and treated coir pith as potential component of cementitious composites. The studied material is coir pith originating from a coconut production. Its applicability as cement mixture component was assessed in terms of the physical properties of concrete containing different amount of coir pith. Basic physical properties, compressive and bending strength, and hygric transport characteristics as well as thermal properties belong among the studied characteristics. It was proved that the concrete with $5 \%$ (by mass of cement) of this waste material shows appropriate physical properties and it gives rise to an applicable material for building structures. Generally, the coir pith can be regarded as lightening additive. When $10 \%$ of coir pith was added, it has led to higher deterioration of properties than what is acceptable since such dosing is greatly increasing the total porosity. The influence of chemical treatment of coir pith was evaluated as well; both tested treatment methods improved the performance of cementitious composites while the acetylation was somewhat more effective the treatment by $\mathrm{NaOH}$.
\end{abstract}

\section{Introduction}

Concrete is conventionally produced from Portland cement, water, and aggregates but nowadays virtually whole world concrete production applies also other components (additives, admixtures) in order to improve the concrete properties, cut production costs, or reduce environmental impactthat is, energy and natural resources consumption-of concrete production. One of the most widely studied and used groups of concrete additives represents supplementary cementitious materials (SCM). SCM can be used as a partial cement replacement in concrete production [1]. Therefore, the utilization of these kinds of materials can lead to a decrease of cement consumption. Cement is one of the most utilized building materials and its production is one of the biggest producers of $\mathrm{CO}_{2}$ emissions. Approximately 1 ton of the greenhouse gas (according to the production technology) per 1 ton of cement is generated [2]. Thus, the reduction of cement consumption has an economical as well as an ecological advantage. The most common representatives of SCM are industrial byproducts. Their applications bring another ecological advantage; waste material is reutilized instead of being disposed. The most well-known byproducts employed as a cement replacement are, for example, fly ash [3], silica fume [4], blast furnace slag [5], or fine ground brick [6]. Another group of SCM representatives is composed of those materials, which have to be pretreated (usually burned for its specific temperature) for obtaining pozzolanic properties. It is, for example, metakaolin [7], some other burned clays [8], or microsilica [9].

All mentioned SCM are artificial materials, originating in a manufacturing process. However, as cement replacement can be also used as natural materials, more common are natural minerals such as zeolites [10], tuff, and diatomite; however, also some organic materials show pozzolanic activity. During the last few decades, the application of agricultural 
waste gains on importance. An agroindustrial economy of many countries is frequently based on a production of agricultural materials and their further treatments. A huge problem, significantly affecting a sustainability of the process, becomes a disposal of biomass. Although technologies for its treatment (e.g., transformation into the energy) have been already developed, a biomass is still not commonly utilized. Unfortunately, it is mainly being disposal, left on fields, or burned up. This usually happens in underdeveloped countries, which have almost no regulatory possibilities for changing these heavily polluting methods, spoiling environment. Agricultural biomass can be found, for example, in form of stems, leaves, residual straw, roots, hulls, and shells, and it originates from crop plants as sugar cane, wheat, maize, coconut palm, oil palm, rice, cotton, bamboo, and so forth. Recycling of this waste and its further application in civil engineering could solve pollution problems, and it could also lead to a conservation of natural resources. The most common agricultural waste, utilized as SCM, is a rice husk ash. Its application as Portland cement replacement up to $30 \%$ was studied by Muthadhi and Kothandaraman [11]. They proved that a rice husk ash is a reactive pozzolana, which improves mechanical strength as well as other properties. Gastaldini et al. [12] also dealt with this alternative pozzolana; they proved positive effect of a rice husk ash on concrete shrinkage as well as its resistance against chlorides. A corn cob ash can be used in form of cement replacement also. According to the study of Adesanya and Raheem [13], improvement of chemical resistance of concrete was observed in all studied mixtures with a corn cob ash up to $15 \%$. Zhang et al. [14] studied the effect of a wheat husk ash, and they reported improvement of workability and compressive strength of concrete mixtures. Possibilities of utilization of a bagasse ash as SCM were studied by Chi [15] and also by Ganesan et al. [16]. According to Ganesan et al., the best solution was found in $20 \%$ replacement, while Chi reported $10 \%$ as the best ratio of cement replacement.

In this paper, the studied material is agricultural waste originating in a coconut production. Very little attention was paid to this topic and only few papers dealing with this topic were found in common sources. Olanipekun et al. [17] performed the comparative study of concrete properties using coconut shells and palm kernel shell as coarse aggregates. They concluded that, by utilization of the coconut shells, costs of a concrete production are reduced by $30 \%$. Gunasekaran et al. [18] did research dealing with coconuts shells also. They tried to replace a part of a coarse aggregate by these shells and they studied its influence on plastic shrinkage and deflection characteristic of a concrete slab. They reported decrease of plastic shrinkage thanks to the utilized coconut shells. In their other study [19], they focused on a lightweight concrete with coconut shells as a coarse aggregate and Gunasekaran et al. studied its flexural properties. Mechanical strengths showed similar values as in the case of other lightweight concretes. Concrete with coconut fibres reinforcement was the matter of the study performed by Ramli et al. [20]. They studied influence of three types of aggressive environments on strength and durability of the concrete. Ramli et al.
[20] investigated 12-year-old mortar blocks reinforced by coir fibers; they found them unaffected by the cementitious environment. Abdullah et al. [21] studied mechanical properties and fracture behaviour of coconut fibre-based green composites. They proved that the highest strength of modulus of rupture and compressive strength were achieved in the case of $9 \%$ of coconut fibres reinforcement. Utilization of coir fibres as well as of a coir pith as cement replacement was the matter of the study performed by Sonia and Dasan [22]. They focused on mechanical properties, water imbibing, and microbial growth.

The utilization of a coir pith as concrete additive is the matter of this study. Coir piths with three different chemical treatments were used as additive in dosing of 5 and $10 \%$ of Portland cement content in concrete mixtures. Its applicability was investigated by means of physical characteristics determination. Among studied properties belong the basic physical characteristic, mechanical strength, hygric transport parameters, and thermal properties. Achieved results were compared with the reference material, concrete with no coir pith added.

\section{Material and Samples}

Compositions of studied concrete mixtures are presented in Table 1. Portland cement CEM I 52.5 R was used as the main binder component. Its chemical composition (obtained by XRF methods) is presented in Table 2, while its mineralogical composition according to Bogue is in Table 3. The utilized coconut coir pith was obtained from the Gudiyattam consortium of the state Tamil Nadu (India). As a secondary product of coir fibres extraction from outer protective peel of a coconut, the coir pith was separated mechanically, cleaned, and dried. The coir pith has a lignocellulose nature and it is composed of $2-3 \%$ short fibres and cork. It contains high amount of lignin $(31 \%)$ and cellulose $(27 \%)$ and a ratio of carbon-nitrogen is around $100: 1$. Thanks to the high content of lignin, the coir pith is resistant to a biological degradation. The coir pith was treated in order to increase its durability in cementitious matrix and also to reduce its negative effect on the cement hydration course. Two different treatments were tested and compared with untreated coir pith: acetylation by help of acetic anhydride and alkaline treatment by sodium hydroxide. The dosing of coir pith in composite was set as $5 \%$ and $10 \%$ of cement mass. Summary of the utilized coir pith is shown in Table 4 and their granulometry is presented in Figure 1. The granulometry of treated coir pith was somewhat coarser since the fine particles were lost during the treatment. Other components of designed concrete mixtures were four gradings of silica sand with $98.5 \%$ amount of $\mathrm{SiO}_{2}$ and plasticizer SIKA 1035 (based on polycarboxylate ether). Water/cement ratio was set as 0.52 in all cases of studied mixtures.

The measurements of material parameters of hardened concrete specimens were performed after 28 days of standard curing $(100 \% \mathrm{RH})$. It took place in a conditioned laboratory at the temperature of $22 \pm 1^{\circ} \mathrm{C}$ and $25-30 \%$ of relative humidity. List of utilized specimens for particular measurement is presented in Table 5. 
TABLE 1: Composition of concrete mixtures $\left(\mathrm{kg} / \mathrm{m}^{3}\right)$.

\begin{tabular}{lccccccc}
\hline & Ref & A-5 & A-10 & B-5 & B-10 & C-5 & C-10 \\
\hline Silica sand 0.1/0.6 mm & 500 & 500 & 500 & 500 & 500 & 500 & 500 \\
Silica sand & 321 & 321 & 321 & 321 & 321 & 321 & 321 \\
$0.3 / 0.8 \mathrm{~mm}$ & & & & & & & \\
Silica sand 0.6/1.2 mm & 250 & 250 & 250 & 250 & 250 & 250 & 250 \\
Silica sand 1/4 mm & 179 & 179 & 179 & 179 & 179 & 179 & 179 \\
Plasticizer SIKA 1035 & 5.4 & 5.4 & 5.4 & 5.4 & 5.4 & 5.4 & 5.4 \\
CEM I 52.5 R & 563 & 563 & 563 & 563 & 563 & 563 & 563 \\
Coir pith A type & 0 & 26.8 & 53.6 & 0 & 0 & 0 & 0 \\
Coir pith B type & 0 & 0 & 0 & 26.8 & 53.6 & 0 & 0 \\
Coir pith C type & 0 & 0 & 0 & 0 & 0 & 26.8 & 53.6 \\
W/C ratio & 0.52 & 0.52 & 0.52 & 0.52 & 0.52 & 0.52 & 0.52 \\
\hline
\end{tabular}

TABLE 2: Chemical composition of cement CEM I 52.5 R.

\begin{tabular}{lc}
\hline Component & Amount [\% by mass] \\
\hline $\mathrm{CaO}$ & 64.9 \\
$\mathrm{SiO}_{2}$ & 18.1 \\
$\mathrm{Al}_{2} \mathrm{O}_{3}$ & 6.4 \\
$\mathrm{Fe}_{2} \mathrm{O}_{3}$ & 2.4 \\
$\mathrm{MgO}$ & 1 \\
$\mathrm{Na}_{2} \mathrm{O}$ & 0.3 \\
$\mathrm{~K}_{2} \mathrm{O}$ & 1.2 \\
$\mathrm{SO}_{3}$ & 4.9 \\
$\mathrm{P}_{2} \mathrm{O}_{5}$ & 0.2 \\
\hline
\end{tabular}

TABLE 3: Mineralogical composition of cement CEM I 52.5 R.

\begin{tabular}{lc}
\hline Component & Amount [\% by mass] \\
\hline $\mathrm{C}_{3} \mathrm{~S}$ & 66.1 \\
$\mathrm{C}_{2} \mathrm{~S}$ & 2.3 \\
$\mathrm{C}_{3} \mathrm{~A}$ & 12.9 \\
$\mathrm{C}_{4} \mathrm{AF}$ & 7.3 \\
\hline
\end{tabular}

TABLE 4: Chemical treatment of coir piths.

\begin{tabular}{lcc}
\hline & Treatment of coir pith & Matrix density $\left[\mathrm{kg} \mathrm{m}^{-3}\right]$ \\
\hline Coir pith A & Untreated & 1535 \\
Coir pith B & Sodium hydroxide treated & 1403 \\
Coir pith C & Acetylation treated & 1341 \\
\hline
\end{tabular}

\section{Experimental Methods}

3.1. Basic Physical Properties. Bulk density, matrix density, and open porosity were measured using the water vacuum saturation method [23]. Each sample was dried in a drier to remove majority of the physically bound water. After that, the samples were placed into a desiccator with deaired water. During three hours, air was evacuated with a vacuum pump from the desiccator. The samples were then kept under water for not less than 24 hours.

Characterization of a pore structure was determined by the mercury intrusion porosimetry. This method is based

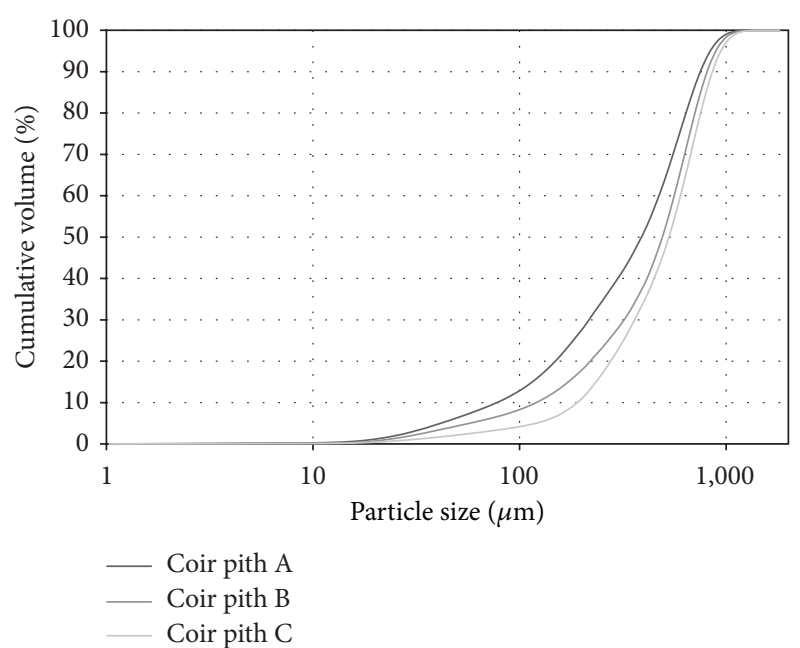

FIGURE 1: Granulometry curves of three types of coir pith.

TABLE 5: List of specimens.

\begin{tabular}{lcc}
\hline Measurement & Dimension $[\mathrm{mm}]$ & $\begin{array}{c}\text { Number of } \\
\text { samples }\end{array}$ \\
\hline $\begin{array}{l}\text { Water vacuum } \\
\text { saturation method }\end{array}$ & $50 \times 50 \times 50$ & 3 \\
$\begin{array}{l}\text { Cups methods } \\
\text { Absorption }\end{array}$ & $50 \times 50 \times 50$ & 3 \\
$\begin{array}{l}\text { experiment } \\
\text { Thermal properties }\end{array}$ & $70 \times 70 \times 70$ & 3 \\
$\begin{array}{l}\text { Porosimetry } \\
\text { Mechanical } \\
\text { properties }\end{array}$ & $50 \times 50 \times 50$ & 3 \\
\hline
\end{tabular}

on the determination of the external pressure needed to force the mercury into a pore against the opposing force of the liquid's surface tension. The pore size is then calculated from the measured pressure using Washburn's equation. The experiments were carried out using instruments PASCAL 140 and 440 (Thermo Scientific). The range of an applied pressure corresponds to the pore radius from $10 \mathrm{~nm}$ to $100 \mu \mathrm{m}$.

3.2. Mechanical Properties. Mechanical properties as compressive strength and bending strength were measured according to standards [24]. A measurement of bending strength was performed using the loading device MTS 100. An arrangement of the experiment was the classical threepoint bending with $100 \mathrm{~mm}$ span length. For determination of compressive strength, special loading device EU40 was employed. The samples from the measurement of bending strengths were used. In the actual experiment, samples were put between two steel pressure plates with dimensions of 40 $\times 40 \mathrm{~mm}$. Great emphasis was given to the centring of the arrangement, since only simple compression should act.

3.3. Hygric Properties. Measurement of water vapour transport parameters was performed applying the cup methods (dry-cup and wet-cup) [25]. The aim of this measurement is 
to make two environments with different water vapour partial pressure. In dry-cup arrangement, cup contains silica gel, which simulates $5 \%$ relative humidity. Specimens were water and vapour proof insulated on four lateral sides. The aim of the insulating was to reach one dimension transport. Then, they were put on the cups with silica gel and there they were air-sealed fixed. Cups were then placed into a climatic chamber which keeps temperature of $25^{\circ} \mathrm{C}$ and relative humidity of $50 \%$. For two weeks, cups were periodically weighted. The steady state values of mass gain or mass loss determined by linear regression for the last five readings were used for the determination of water vapour diffusion resistance factor. After two weeks, measurement cups were remade to the wetcup arrangement; it means that silica gel is exchanged for water, which simulates relative humidity of $95 \%$. Otherwise, experimental process of wet-cup measurement is the same as in the case of dry-cup.

The water liquid transport was characterized by the water absorption coefficient. Specimens were insulated, as in the case of water vapour transport, on four lateral sides. Then, the face side of specimens was immersed $1-2 \mathrm{~mm}$ in the water. Constant water level in the tank was achieved by a Mariotte bottle with two capillary tubes. One of them, inside diameter of $2 \mathrm{~mm}$, was ducked under the water level. The second one, inside diameter of $5 \mathrm{~mm}$, was above water level. The automatic balance allowed for recording the increase of mass. The water absorption coefficient was calculated from the sorptivity plot [26] which was set up from measured data. Apparent moisture diffusivity was calculated from water absorption coefficient by Kumaran equation [27], but this is just for an approximation of the real values of apparent moisture diffusivity. This value depends on moisture content, which is disregarded in Kumaran relation.

3.4. Thermal Properties. Using the device ISOMET 2104 [28], thermal conductivity and specific heat capacity were determined. This commercial device applies a dynamic measurement method so that time of a measurement reduces to dozens of minutes. The measurement process is based on an analysis of a temperature response of an analysed material to heat flow impulses. The heat flow is induced in a resistor of a probe by a distributed electric power. The temperature is recorded and evaluated from the polynomial regression. Both thermal properties were determined in dependence on moisture content.

\section{Results and Discussion}

4.1. Basic Physical Properties. Results obtained from the water vacuum saturation method are summarized in Table 6 while the pore size distribution is shown in Figure 2. The highest value of bulk density and also matrix density was obtained by the reference material with no coir pith. Dosage of 5\% of the coir pith leads to the bulk density decrease by about $10 \%$ and dosage of $10 \%$ causes the fall by about $24 \%$ what is obviously caused by low bulk density of coir pith. The matrix density of pure coir pith (Table 4) is lower than what is typical for silicates (about $2500 \mathrm{~kg} \mathrm{~m}^{-3}$ ); thus, the values of matrix density of composites also go down with
TABLE 6: Basic physical properties.

\begin{tabular}{lccc}
\hline Material & $\begin{array}{c}\text { Bulk density } \\
{\left[\mathrm{kg} \mathrm{m}^{-3}\right]}\end{array}$ & $\begin{array}{c}\text { Matrix density } \\
{\left[\mathrm{kg} \mathrm{m}^{-3}\right]}\end{array}$ & $\begin{array}{c}\text { Open porosity } \\
{[\%]}\end{array}$ \\
\hline Ref. & 2072 & 2526 & 18.0 \\
A-5 & 1857 & 2307 & 19.5 \\
A-10 & 1602 & 2214 & 27.6 \\
B-5 & 1846 & 2287 & 19.3 \\
B-10 & 1564 & 2178 & 29.0 \\
C-5 & 1874 & 2303 & 18.6 \\
C-10 & 1588 & 2208 & 28.1 \\
\hline
\end{tabular}

TABLE 7: Mechanical properties.

\begin{tabular}{lcc}
\hline Material & $\begin{array}{c}\text { Compressive strength } \\
{[\mathrm{MPa}]}\end{array}$ & $\begin{array}{c}\text { Bending strength } \\
{[\mathrm{MPa}]}\end{array}$ \\
\hline Ref. & 63.1 & 9.8 \\
A-5 & 40.1 & 9.3 \\
A-10 & 15.2 & 4.3 \\
B-5 & 47.6 & 8.5 \\
B-10 & 12.8 & 4.1 \\
C-5 & 48.3 & 9.5 \\
C-10 & 14.5 & 4.5 \\
\hline
\end{tabular}

growing amount of coir pith. In the case of $5 \%$ coir pith, the matrix density decreases by $9 \%$ and in the case of $10 \%$ it goes down by $13 \%$. Changes of open porosities, calculated from the above discussed values, are negligible when coir pith dosing is just 5\% of cement. Higher difference can be observed in the higher amount of utilized coir pith. Changes in pore structure of concrete material containing coir pith are more obvious from measured pore size distribution curves (Figure 2). The presence of coir pith caused increase of wide range of capillary pores (diameter of 0.1 to $100 \mu \mathrm{m}$ ) volume. No distinct influence of chemical treatment of individual types of coir pith can be observed, because achieved values of basic physical properties of concrete with different treated coir pith are almost equal.

4.2. Mechanical Properties. Compressive strength and bending strength of composites are presented in Table 7. The utilization of coir pith always leads to the compressive strength fall and the reference material shows the highest value. Generally, it can be deduced that by replacing $10 \%$ of cement by coir pith (regardless of chemical treatment) compressive strength decreases by about almost 78\%. However, in the case of 5\% replacement, achieved results differ and the influence of chemical treatment can be observed. Concrete containing coir pith with no chemical treatment achieved compressive strength by $36 \%$ lower; the chemical treated coir pith (both sodium hydroxide and acetic acid treatment) reduced the compressive strength just by about $24 \%$. Bending strengths achieve almost similar values in the case of the reference material and the concretes with $5 \%$ of coir pith. When material contains $10 \%$ of studied coir pith, it leads to the bending strength decrease by $56 \%$. In the case of 


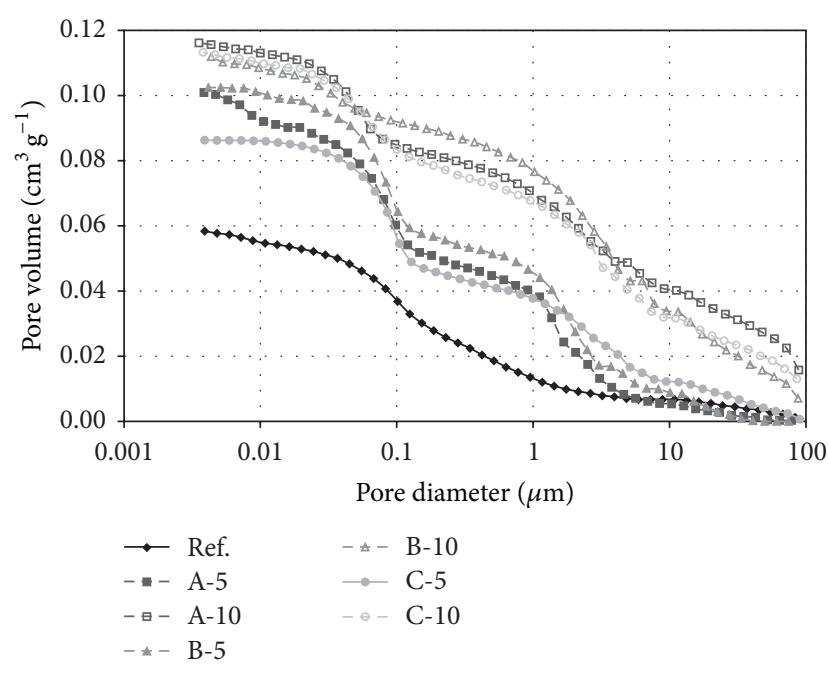

FIGURE 2: Pore size distribution curve.

TABLE 8: Water vapour transport parameters: dry-cup arrangement.

\begin{tabular}{lccc}
\hline Material & $\begin{array}{c}\text { Water vapour } \\
\text { diffusion } \\
\text { permeability } \\
{[\mathrm{s}]}\end{array}$ & $\begin{array}{c}\text { Water vapour } \\
\text { diffusion } \\
\text { coefficient } \\
{\left[\mathrm{m}^{2} \mathrm{~s}^{-1}\right]}\end{array}$ & $\begin{array}{c}\text { Water vapour } \\
\text { diffusion } \\
\text { resistance factor }\end{array}$ \\
\hline Ref. & $3.30 E-12$ & $4.53 E-07$ & 50.9 \\
A-5 & $3.46 E-12$ & $4.75 E-07$ & 48.4 \\
A-10 & $6.71 E-12$ & $9.23 E-07$ & 24.9 \\
B-5 & $3.78 E-12$ & $5.19 E-07$ & 44.5 \\
B-10 & $6.55 E-12$ & $9.00 E-07$ & 25.8 \\
C-5 & $3.71 E-12$ & $5.09 E-07$ & 45.3 \\
C-10 & $6.55 E-12$ & $9.00 E-07$ & 25.6 \\
\hline
\end{tabular}

TABLE 9: Water vapour transport parameters: wet-cup arrangement.

\begin{tabular}{lccc}
\hline Material & $\begin{array}{c}\text { Water vapour } \\
\text { diffusion } \\
\text { permeability } \\
{[\mathrm{s}]}\end{array}$ & $\begin{array}{c}\text { Water vapour } \\
\text { diffusion } \\
\text { coefficient } \\
{\left[\mathrm{m}^{2} \mathrm{~s}^{-1}\right]}\end{array}$ & $\begin{array}{c}\text { Water vapour } \\
\text { diffusion } \\
\text { resistance factor } \\
{[-]}\end{array}$ \\
\hline Ref. & $4.69 E-12$ & $6.45 E-07$ & 37.1 \\
A-5 & $5.89 E-12$ & $8.09 E-07$ & 32.3 \\
A-10 & $1.80 E-11$ & $2.48 E-06$ & 9.3 \\
B-5 & $5.86 E-12$ & $8.06 E-07$ & 29.0 \\
B-10 & $1.48 E-11$ & $1.99 E-06$ & 11.4 \\
C-5 & $8.93 E-12$ & $1.23 E-06$ & 29.7 \\
C-10 & $2.24 E-11$ & $3.07 E-06$ & 9.6 \\
\hline
\end{tabular}

bending strength, the influence of chemical treatments was not proved.

4.3. Hygric Properties. Measured water vapour transport properties are presented in Table 8 (dry-cup arrangement) and Table 9 (wet-cup arrangement). Both arrangements show different results; values of water vapour diffusion resistance
TABLE 10: Liquid water transport parameters.

\begin{tabular}{lcc}
\hline Material & $\begin{array}{c}\text { Water absorption } \\
\text { coefficient } \\
{\left[\mathrm{kg} \mathrm{m}^{-2} \mathrm{~s}^{-1 / 2}\right]}\end{array}$ & $\begin{array}{c}\text { Apparent moisture } \\
\text { diffusivity } \\
{\left[\mathrm{m}^{2} \mathrm{~s}^{-1}\right]}\end{array}$ \\
\hline Ref. & 0.018 & $7.72 E-08$ \\
A-5 & 0.019 & $9.92 E-08$ \\
A-10 & 0.193 & $4.73 E-06$ \\
B-5 & 0.019 & $1.00 E-07$ \\
B-10 & 0.199 & $6.30 E-06$ \\
C-5 & 0.020 & $1.15 E-07$ \\
C-10 & 0.241 & $8.71 E-06$ \\
\hline
\end{tabular}

factor obtained by dry-cup are always higher than the values from wet-cup. It is well-known phenomenon, which was observed also in the case of other materials. It is caused probably by a partial transport of capillary condensed water at higher relative humidity [29]. Regarding influence of coir pith admixture, when using $5 \%$ of this material, the water vapour diffusion resistance factor decreases slightly. In the case of materials with no chemical treatment, the fall is 5\% in dry-cup arrangement (13\% in wet-cup arrangement). When chemical treated coir pith is used, the decrease is $13 \%$ in dry-cup arrangement (21\% in wet-cup arrangement). Major fall can be observed in the case of higher amount of coir pith. All concretes containing $10 \%$ of coir pith show by about $50 \%$ lower water vapour diffusion resistance factor in dry-cup arrangement, while in wet-cup arrangement the fall is about $73 \%$.

In Table 10, values of water absorption coefficient and apparent moisture diffusivity, which described water liquid transport, are shown. 5\% of coir pith replacement has (as in the case of open porosity) almost no effect; measured data are essentially equal. But when replacing $10 \%$ of concrete by coir pith, the capability of water liquid transport increases rapidly; it grows by more than $91 \%$ in all cases of studied concrete. Achieved results correspond with changes of open porosity, which is the main influencing characteristic for water liquid transport.

4.4. Thermal Properties. Coefficient of thermal conductivity $\lambda$ depending on the volumetric moisture content is shown in Figure 3 . In the case of concretes with $5 \%$ coir pith additive, $\lambda$ falls about $20 \%$ in dry state. When the material contains $10 \%$ of coir pith, its thermal conductivity decreases by almost $56 \%$ in comparison with the reference concrete with no coir pith. It is obvious that as the moisture content grows, the thermal conductivity of concrete is increasing. This tendency is a common phenomenon caused by different values of the thermal conductivity of water and air in pores and voids.

In Figure 4, the dependency of specific heat capacity on volumetric moisture content is presented. As in the case of thermal conductivity, also these properties show growing trend with increasing moisture content. The reason for this behaviour is also the same like in the previous case; values of specific heat capacity of water and air vary widely. The reference concrete shows the lowest values of specific heat 


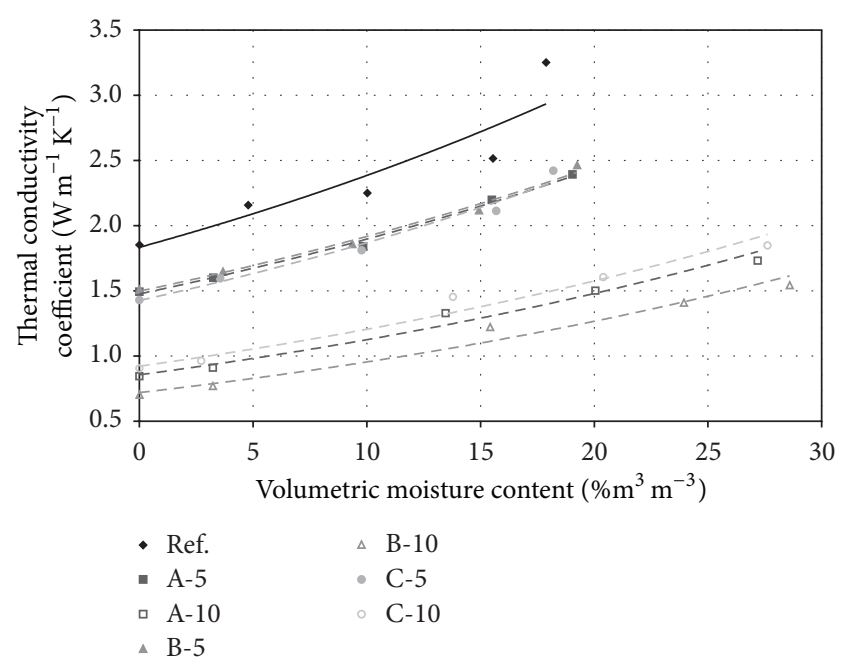

FIGURE 3: Influence of moisture and coir pith admixture on coefficient of thermal conductivity.

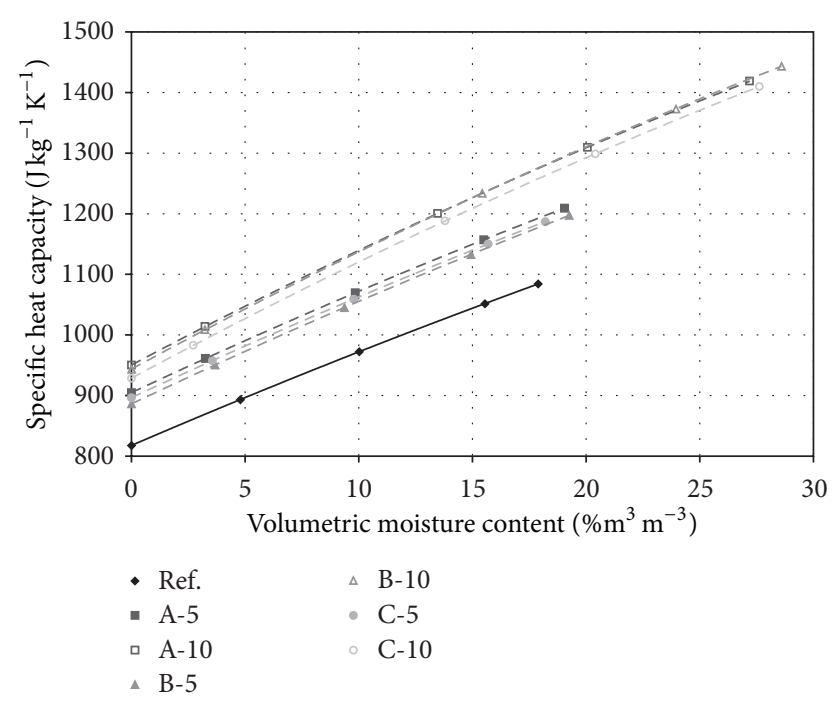

FIGURE 4: Influence of moisture and coir pith additive on specific heat capacity.

capacity. When coir pith is used, it always leads to specific heat capacity increase. In the case of 5\% cement replacement, the growth is by about $9 \%$. Concretes containing $10 \%$ of coir pith reach values by about $13 \%$ higher than the reference material. From achieved results of thermal characteristic, it can be deduced that utilization of coir pith leads to improvement of thermal insulating capabilities of concrete due to the lightening of concrete; the specific heat capacity, that is, ability of material to accumulate heat, is also improved by coir pith admixing.

\section{Conclusions}

The matter of this paper was to determine possibilities of utilization of coir pith as component of cementitious materials. Coir pith is agricultural waste originating in coconut production. Its utilization in concrete production would have both economic and ecologic advantages. The aims of this study were to find out appropriate amount of coir pith dosing and also to determine influence of chemical treatment of the waste material on physical properties of concrete. Studied coir pith had three different forms of chemical treatments: no treatment, sodium hydroxide treatment, and acetylation treatment by help of acetic anhydride. Six concrete mixtures differed in amount of coir pith dosing (5\% or $10 \%$ of cement content) and in type of used coir pith. Achieved results were compared with the reference material with no coir pith. The influence of utilized coir pith can be summarized as follows:

(i) Utilization of $5 \%$ coir pith led to bulk density decrease (by about 10\%), matrix density decrease (by about $9 \%$ ), and almost no changes in open porosity. When $10 \%$ of this waste material was used, bulk density and matrix density went down more substantially (by about $24 \%$, resp., by $13 \%$ ), while open porosity decreased by $10 \%$. No considerable influence of chemical treatment on porosity was observed.

(ii) Mechanical properties were also decreased by utilization of coir pith. Compressive strength of concrete containing $10 \%$ of coir pith went down by almost $78 \%$; therefore, utilization of such amount of waste material is not useful. However, utilization of 5\% of SCM leads to quite appropriate results. In this case, positive effect of chemical treatment was proved. When chemical treated coir pith was used, values of compressive strength fell down by about $24 \%$. Regarding bending strength, $5 \%$ of coir pith led to comparable values like in the case of reference material. When higher percentage of the waste material was used, bending strength decreased by about $56 \%$.

(iii) Measured hygric properties can be divided into two parts according to physical state of water. Water liquid transport characteristic and water vapour transport characteristic were measured. It was proved that by utilization of $5 \%$ of coir pith ability of water transport was comparable with reference concrete. However, when $10 \%$ of cement was replaced, water transport ability increases considerably.

(iv) Thermal properties show high dependency on moisture content. However, regarding the influence of coir pith utilized as cement replacement, it was proved that this waste material improved thermal insulating abilities of final concrete. The higher amount of coir pith material contains the better thermal insulator concrete is.

The experimental results summarized above show that although utilization of coir pith would be positive from the economic as well as environmental point of view, its applicability is limited by final physical properties of concrete. In our study, $5 \%$ of coir pith dosage leads to appropriate building material. When $10 \%$ of this waste material is used, physical properties are deteriorated more than what is acceptable. 


\section{Conflict of Interests}

The authors declare that there is no conflict of interests regarding the publication of this paper.

\section{Acknowledgments}

This research has been supported by the Grant Agency of the Czech Technical University in Prague, Grant no. SGS13/ $165 / \mathrm{OHK} 1 / 3 \mathrm{~T} / 11$, by the European Social Fund within the framework of realizing the Project "CZ.1.07/2.3.00/30.0034, Support of Intersectoral Mobility and Quality Enhancement of Research Teams at Czech Technical University in Prague" and by the European Union OP RDI Project "CZ.1.05/2.1.00/ 03.0091, University Centre for Energy Efficient Buildings.”

\section{References}

[1] K. L. Scrivener and A. Nonat, "Hydration of cementitious materials, present and future," Cement and Concrete Research, vol. 41, no. 7, pp. 651-665, 2011.

[2] A. Hasanbeigi, L. Price, and E. Lin, "Emerging energy-efficiency and $\mathrm{CO}_{2}$ emission-reduction technologies for cement and concrete production: a technical review," Renewable \& Sustainable Energy Reviews, vol. 16, no. 8, pp. 6220-6238, 2012.

[3] E. Vejmelková, M. Pavlíkova, M. Keppert et al., "Fly ash influence on the properties of high performance concrete," Cement Wapno Beton, vol. 14, no. 4, pp. 189-204, 2009.

[4] A. A. Almusallam, H. Beshr, M. Maslehuddin, and O. S. B. AlAmoudi, "Effect of silica fume on the mechanical properties of low quality coarse aggregate concrete," Cement \& Concrete Composites, vol. 26, no. 7, pp. 891-900, 2004.

[5] E. Vejmelková, M. Jerman, P. Konvalinka, S. Grzeszczyk, and R. Černý, "Durability properties of self compacting concrete produced using blast furnace slag," in 2nd International Symposium on Design, Performance and Use of Self-Consolidating Concrete, vol. 65, pp. 343-350, RILEM Publications, 2009.

[6] E. Vejmelková, M. Keppert, P. Rovnaníková, M. Ondráček, Z. Keršner, and R. Černý, "Properties of high performance concrete containing fine-ground ceramics as supplementary cementitious material," Cement \& Concrete Composites, vol. 34, no. 1, pp. 55-61, 2012.

[7] P. Reiterman, M. Keppert, M. Čáchová et al., "Permeability and basic physical properties of concrete with metakaolin addition," Applied Mechanics and Materials, vol. 486, pp. 313-318, 2014.

[8] A. Tironi, M. A. Trezza, A. N. Scian, and E. F. Irassar, "Assessment of pozzolanic activity of different calcined clays," Cement \& Concrete Composites, vol. 37, no. 1, pp. 319-327, 2013.

[9] A. Elahi, Q. U. Z. Khan, S. A. Barbhuiya, P. A. M. Basheer, and M. I. Russell, "Hydration characteristics of cement paste containing supplementary cementitious materials," Arabian Journal for Science and Engineering, vol. 37, no. 3, pp. 535-544, 2012.

[10] E. Vejmelková, M. Keppert, M. Ondráček, and R. Černý, "Effect of natural zeolite on the properties of high performance concrete," Cement Wapno Beton, vol. 18, no. 3, pp. 150-159, 2013.

[11] A. Muthadhi and S. Kothandaraman, "Experimental investigations of performance characteristics of rice husk ash-blended concrete," Journal of Materials in Civil Engineering, vol. 25, no. 8, pp. 1115-1118, 2013.
[12] A. L. G. Gastaldini, M. P. Da Silva, F. B. Zamberlan, and C. Z. M. Neto, "Total shrinkage, chloride penetration, and compressive strength of concretes that contain clear-colored rice husk ash," Construction and Building Materials, vol. 54, no. 3, pp. 369-377, 2014.

[13] D. A. Adesanya and A. A. Raheem, "A study of the permeability and acid attack of corn cob ash blended cements," Construction and Building Materials, vol. 24, no. 3, pp. 403-409, 2010.

[14] J. Zhang, J. M. Khatib, C. Booth, and R. Siddique, "Possible utilization of wheat husk ash waste in the production of precast concrete elements," in Proceedings of the International Conference on Concrete Construction, pp. 517-521, September 2008.

[15] M.-C. Chi, "Effects of sugar cane bagasse ash as a cement replacement on properties of mortars," Science and Engineering of Composite Materials, vol. 19, no. 3, pp. 279-285, 2012.

[16] K. Ganesan, K. Rajagopal, and K. Thangavel, "Evaluation of bagasse ash as supplementary cementitious material," Cement \& Concrete Composites, vol. 29, no. 6, pp. 515-524, 2007.

[17] E. A. Olanipekun, K. O. Olusola, and O. Ata, "A comparative study of concrete properties using coconut shell and palm kernel shell as coarse aggregates," Building and Environment, vol. 41, no. 3, pp. 297-301, 2006.

[18] K. Gunasekaran, R. Annadurai, and P. S. Kumar, "Plastic shrinkage and deflection characteristics of coconut shell concrete slab," Construction and Building Materials, vol. 43, no. 6, pp. 203-207, 2013.

[19] K. Gunasekaran, R. Annadurai, and P. S. Kumar, "Study on reinforced lightweight coconut shell concrete beam behavior under flexure," Materials \& Design, vol. 46, no. 4, pp. 157-167, 2013.

[20] M. Ramli, W. H. Kwan, and N. F. Abas, "Strength and durability of coconut-fiber-reinforced concrete in aggressive environments," Construction and Building Materials, vol. 38, pp. 554566, 2013.

[21] A. Abdullah, S. B. Jamaludin, M. M. Noor, and K. Hussin, "Mechanical properties and fracture behaviour of coconut fibrebased green composites," Romanian Journal of Materials, vol. 42, no. 1, pp. 23-29, 2012.

[22] A. Sonia and K. P. Dasan, "Mechanical, water imbibing and microbial growth studies of coir fiber/pith substituted cement blocks," in Recent Trends in Advanced Materials, vol. 584 of Advanced Materials Research, pp. 376-380, 2012.

[23] S. Roels, J. Carmeliet, H. Hens et al., "Interlaboratory comparison of hygric properties of porous building materials," Journal of Thermal Envelope and Building Science, vol. 27, no. 4, pp. 307325, 2004.

[24] ČSN, "Methods of test for mortar for masonry-part 11: determination of flexural and compressive strength of hardened mortar," CSN EN 1015-11, Czech Standardization Institute, Prague, Czech Republic, 2000.

[25] ČSN, "Determination of water vapour diffusion coefficient of building materials by method without temperature gradient," ČSN 72 7031, Czech Standardization Institute, 2001.

[26] E. Vejmelková, M. Pavlíková, M. Jerman, and R. Černý, "Free water intake as means of material characterization," Journal of Building Physics, vol. 33, no. 1, pp. 29-44, 2009.

[27] M. K. Kumaran, "Moisture diffusivity of building materials from water absorption measurements," Journal of Thermal Envelope and Building Science, vol. 22, no. 4, pp. 349-355, 1999. 
[28] Applied Precision-ISOMET, ISOMET, Bratislava, Slovakia, 1999.

[29] R. Černý and P. Rovnaníková, Transport Processes in Concrete, Spon Press, London, UK, 2002. 

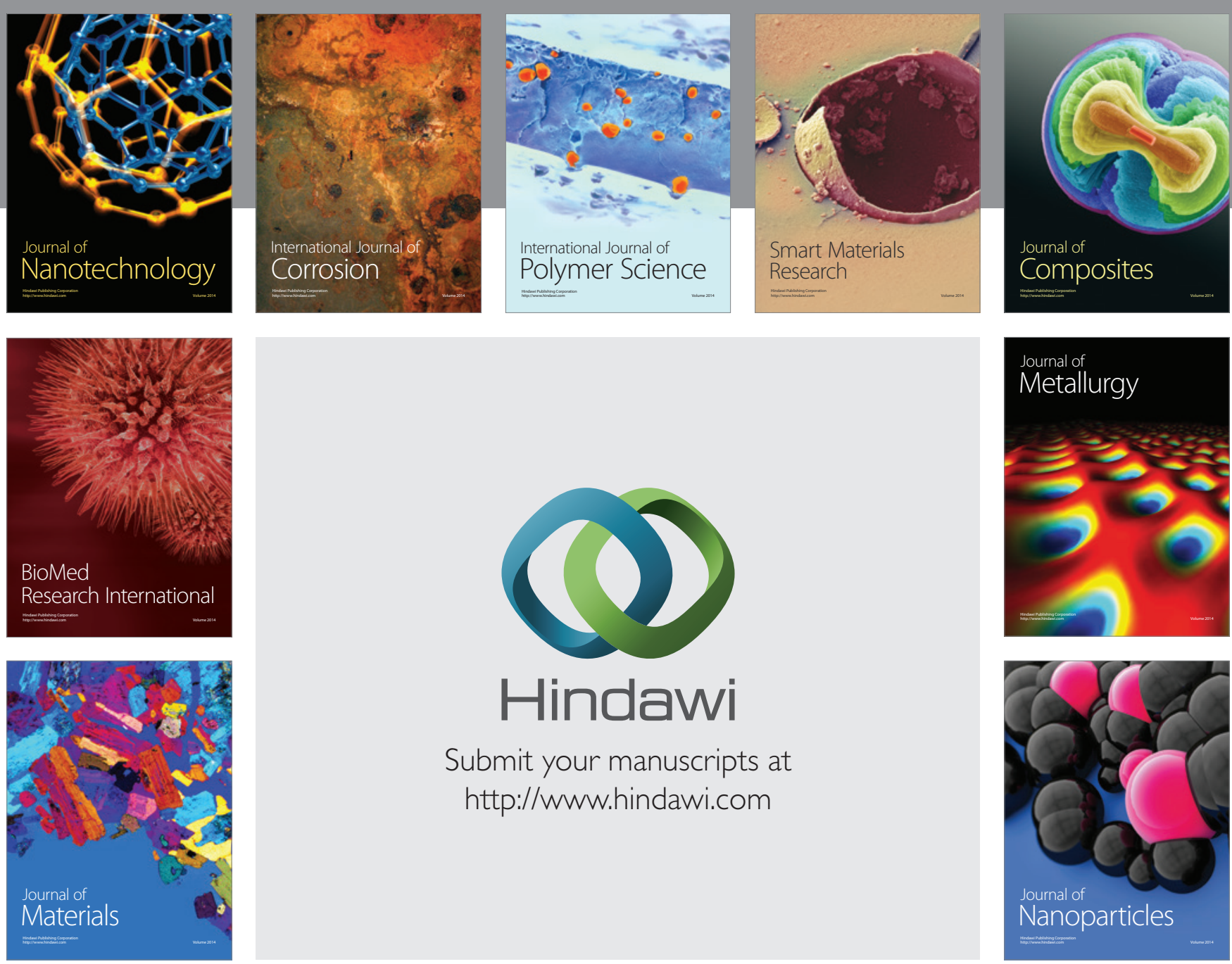

Submit your manuscripts at http://www.hindawi.com
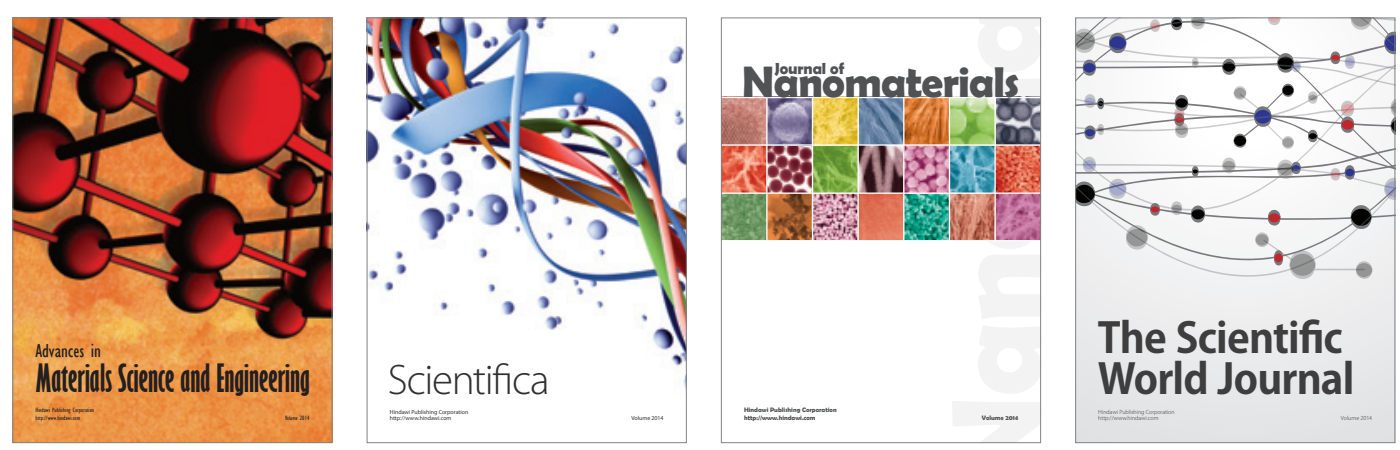

\section{The Scientific World Journal}
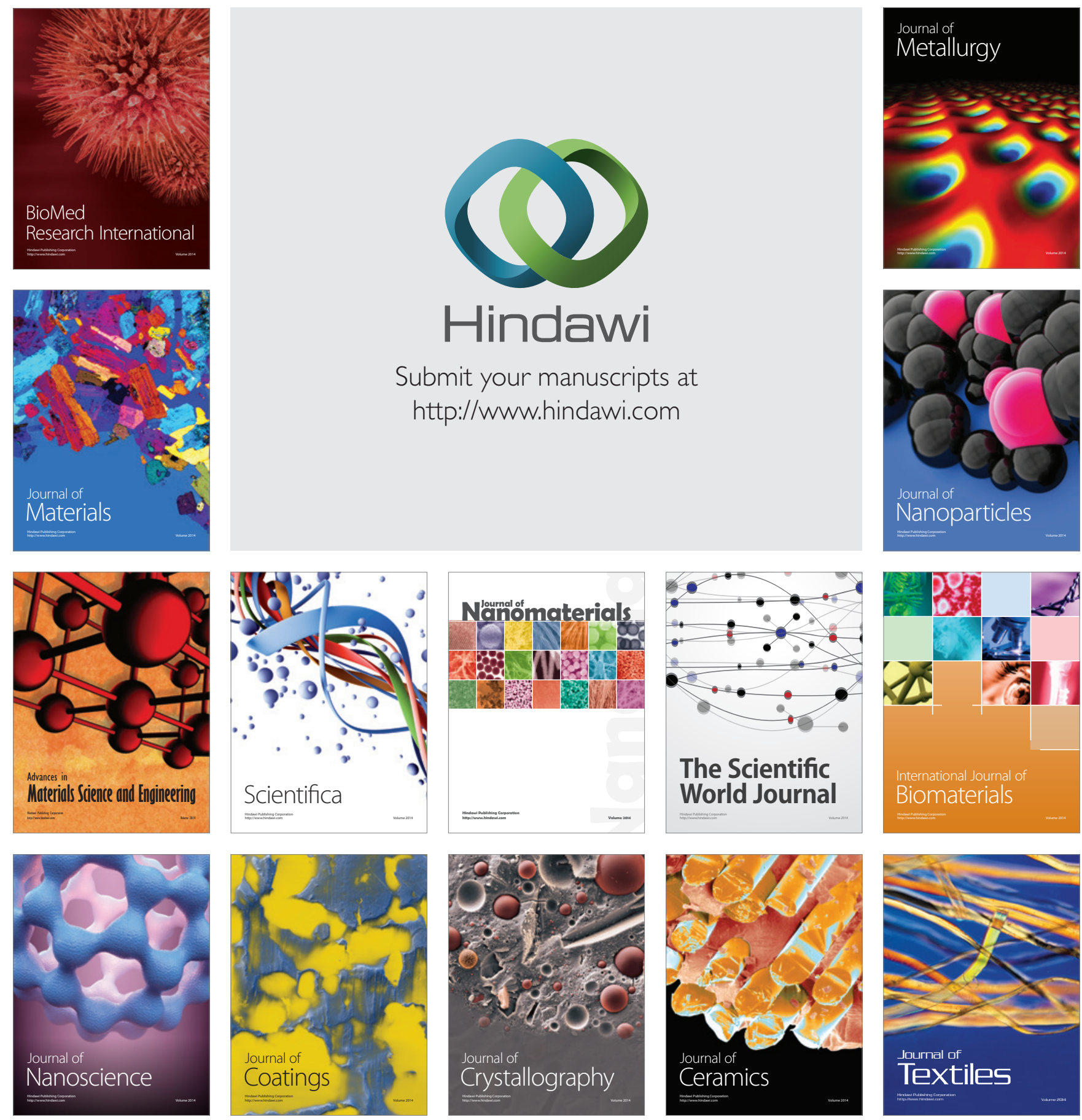